\title{
KYAI SEBAGAI AGEN PERUBAHAN SOSIAL DAN PERDAMAIAN DALAM MASYARAKAT TRADISIONAL
}

\author{
Robby Darwis Nasution \\ Ilmu Pemerintahan Fakultas Ilmu Sosial dan Ilmu Politik Universitas Muhammadiyah Ponorogo \\ E-mail: darwisnasution69@gmail.com
}

\begin{abstract}
ABSTRAK. Globalisasi ekonomi telah merubah struktur masyarakat di dunia ini menjadi jauh dari kata sosialis atau perduli terhadap sesama. Ketidak perdulian ini merupakan salah satu bentuk dari modernisasi masyarakat global dan orientasi hidupnya lebih kepada hukum ekonomi daripada hukum kemanusiaan ataupun agama. Islam Tradisional masih memegang rasa daripada rasionalitas dan menempatkan tokoh agama seperti Kyai sebagai tokoh sentral yang akan selalu dipatuhi oleh kalangan Islam tradisional. Dalam penelitian ini ingin mengungkap lebih jauh bagaimana peran Kyai sebagai agen perubahan di dalam masyarakat tradisional. Metode penelitian yang digunakan dalam penelitian ini adalah Library Research (penelitian kepustakaan) dimana analisis yang dilakukan melalui media cetak, media elektronik serta literatur yang berupa buku ataupun jurnal. Kesimpulan yang bisa diambil dalam penelitian ini adalah Kyai sebagai tokoh sentral di dalam masyarakat tradisional berfungsi sebagai otoritas tertinggi yang selalu dipatuhi dan dipatuhi oleh penganut Islam tradisional. Dengan kepatuhan masyarakat tradisional terhadap sosok Kyai maka terbentuklah otoritas tertinggi yang menauingi masyarakat tersebut dan berfungsi sebagai sistem kontrol dalam masyarakat sehingga terciptalah perdamaian didalam masyarakat tradisional. Dengan demikian, Kyai sebagai otoritas tertinggi didalam masyarakat tradisional juga bisa dikatakan sebagai agen perubahan sosial dan perdamaian.
\end{abstract}

Kata kunci: Kyai, Islam, Perubahan Sosial, Perdamaian, Masyarakat Tradisional.

\section{KYAI AS A AGENT OF CHANGE AND PEACEMAKER IN THE TRADITIONAL SOCIETY}

\begin{abstract}
Economic globalization has changed the structure of society in this world to be far from the word socialist or caring for others. This ignorance is one form of modernization of the global society and its orientation over economic laws rather than humanitarian or religious laws. Traditional Islam still holds sense rather than rationality and places religious leaders such as Kyai as a central figure that will always be obeyed by traditional Islamic. In this research would like to reveal further how the role of Kyai as an agent of change in traditional society. The research method used in this study is Library Research where analysis involve the use of print media, electronic media and books or journals. The conclusion that can be taken in this research is Kyai as a central figure in traditional society function as the highest authority which always adhered and obeyed by adherents of traditional Islam. With the traditional community's adherence to the Kyai figure, the highest authority of the community is established and functioning as a control system in the community to create peace within the traditional society. Thus, Kyai as supreme authority in traditional societies can also be regarded as an agent of social change and peace.
\end{abstract}

Key word: Kyai, Islam, social change, peace, traditional society.

\section{PENDAHULUAN}

Dalam era globalisasi ekonomi, manusia dituntut bergerak cepat untuk mengiringi perkembangan zaman yang juga bergerak semakin cepat. Kemajuan teknologi informasi yang semakin cepat pula telah merubah pola perilaku manusia menjadi tidak perduli terhadap sesame atau individualis, mementingkan kepentingan laba rugi (homoekonomikus) ataupun mengesampingkan agamaa sebagai landasan hidup. Dengan munculnya pola perkembangan manusia yang semakin individualis maka akan memperlebar jarak antara individu satu dengan yang lain. Interaksi dan sosialisasi secara langsung sekarang sudah menjadi hal yang using karena kecanggihan teknologi telah ikut merubah pola interaksi tersebut menjadi pola interaksi secara virtual.

Bila sistem pengetahuan dan sistem kepercayaan mengalami pergeseran, dan sistem nilai yang ada terdesak oleh nilai-nilai lain yang kemudian menggeser kedudukan nilai-nilai lama maka akan terjadi perubahan.
Robertson menjelaskan globalisasi sebagai eskalasi saling ketergantungan global dan intensifikasi kesadaran global dan dicirikan oleh aliran ide lewat migrasi besar-besaran dan mediasi elektronik. (Sandarupa, 2014, hal. 1).

Masyarakat dengan ciri seperti diatas merupakan ciri dari masyarakat modern dimana selain ciri diatas, terdapat ciri khusus dari masyarakat modern yaitu lebih mengedepankan rasionalitas daripada rasa atau perasaan. Masyarakat modern sendiri yang seharusnya menjadi masyarakat yang berbudaya serta maju tetapi pada kenyataanya malah mengalami kemunduran sosial akibat perubahan pola perilaku manual menjadi pola perilaku virtual. Selain hal tersebut, dengan mengutamakan rasional dan keuntungan daripada rasa (cinta kasih) maka wajar sekali jika pada saat sekarang ini banyak terjadi kasus pembunuhan oleh keluarganya sendiri, konflik rumah tangga yang berakhir pada perceraian, korupsi ataupun ketidak pedulian pemimpin negara (pemerintah) terhadap masalah yang dialami rakyatnya. Dengan melihat kenyataan tersebut tentu kita menjadi 
berpikiri kembali terkait dengan hasil dari kemajuan atau modernisasi yang telah dicapai oleh masyarakat ini malah menyebabkan konflik didalamnya dan ketidakstabilan sistem pada struktur masyarakat.

Berbeda dengan apa yang terjadi pada masyarakat modern, masyarakat tradisional cenderung stabil dan tidak banyak timbul konflik yang menghinggapinya. Masyarakat tradisional ini bisa kita lihat di pelosok pulau jawa di daerah-daerah pinggiran yang terutamanya di desa-desa kecil. Jika dalam masyarakat modern telah memasukkan unsur perkembangan teknologi informasi serta kemajuan-kemajuan ilmu pengetahuan yang lain, berbeda dengan masyarakat tradisional yang terkadang masih mencampurkan agama dengan budaya nenek moyang yang bahkan terlihat tidak terpengaruh dengan modernisasi perkembangan teknologi informasi.

Struktur masyarakat tradisional ini cenderung stabil dengan budaya yang masih dipegang teguh sampai saat ini, salah satunya adalah kepatuhan masyarakat terhadap para pemimpin ataupun pemuka agama seperti Kyai. Jika kita melihat kembali perubahan pola perkembangan pada masyarakat yang lebih modern dan berorientasi pada kemajuan teknologi informasi serta komunikasi memiliki kecenderungan banyak terjadi konflik serta tidak terjadinya kestabilan dalam masyarakat. Tetapi berbeda dengan masyarakat tradisional yang masih cenderung mempertahankan budaya nenek moyang dan taat kepada pimimpin atau pemuka agama memiliki pola masyarakat yang cenderung stabil (damai) serta jarang terjadi konflik didalam masyarakat. Maka dari itu sangat menarik sekali jika kita melihat lebih jauh peran Kyai sebagai agen perubahan sosial dan perdamaian dalam masyarakat tradisional.

\section{METODE}

Dalam penelitian ini akan menggunakan Penelitian perpustakaan (library research) sebagai teknik pengumpulan datanya. Library research ini bertujuan untuk mengumpulkan data dan informasi dengan bantuan bermacam-macam material yang terdapat di ruangan perpustakaan, seperti: buku-buku, majalah, dokumen, catatan dan kisah-kisah sejarah dan lain-lainnya. Pada hakekatnya data yang diperoleh dengan penelitian kepustakaan ini dapat dijadikan landasan dasar dan alat utama bagi pelaksanaan penelitian lapangan. Dengan demikian, penelitian ini juga bisa dikatakan juga sebagai penelitian yang membahas data-data sekunder.

\section{HASIL DAN PEMBAHASAN}

\section{Konflik Sosial Didalam Masyarakat}

Perkembangan jaman dan kemajuan teknologi informasi serta komunikasi menimbulkan banyak sekat batas antara manusia satu dengan yang lain serta menciptakan interaksi sosial yang kecenderungan individualis. Perubahan yang terjadi ini akan membawa dampak kurangnya kedekatan antara individu satu dengan yang lain karen apola hubungan interaksi langsung sehingga muncul konflik serta perpecahan dalam kelompok-kelompok masyarakat. Kalau orang Jawa memiliki peribahasa "guyub rukun agawe santoso" mungkin dalam era sekarang ini tidak bisa terjadi karena pola interaksi sudah berubah menjadi pola interaksi modern.

Lewis Coser menggambarkan konflik sebagai perselisihan mengenai nilai-nilai atau tuntutan-tuntutan berkenaan dengan status, kekuasaan, dan sumber-sumber kekayaan yang persediaannya tidak mencukupi. Pihakpihak yang sedang berselisih tidak hanya bermaksud untuk memperoleh barang yang diinginkan, tetapi juga memojokkan, merugikan, atau menghancurkan lawan mereka. Lebih lanjut Coser menyatakan bahwa perselisihan atau konflik dapat berlangsung antara individu, kelompok/perkumpulan, atau antara individu dengan kelompok. Proporsi-proporsi yang menyangkut tentang konflik menurut Weber antara lain (Wirawan, 2012, pp. 71-72):

1. Semakin derajat kemerosotan legitimasi politik penguasa, maka semakin besar kecenderungan timbulnya konflik antara kelas atas dan kelas bawah.

2. Semakin karismatik pimpinan kelompok bawah, semakin besar kemampuan kelompok ini memobilisasi kekuatan dalam suatu sistem, maka semakin besar tekanan kepada penguasa melalui penciptaan suatu sistem undang-undang dan sistem administrasi pemerintahan

Untuk melihat lebih jauh tentang konflik yang terjadi di masyarakat, maka tentunya akan lebih baik lagi untuk mengidentifikasi perbedaan konflik dan konsesus/ integrasi sehingga bisa dilihat lebih jauh tentang dimana letak perbedaan antara keduanya. Menurut Ralf Dahrendorf, dengan membandingkan antara model integrasi dan model konflik, maka akan bisa memahami dinamika yang terjadi dalam masyarakat. (Wirawan, 2012, p. 74).

Sedangkan menurut E.H. Carr, konflik yang terjadi antar negara tidak bisa dihindarkan dalam sistem internasional tanpa otoritas berwenang yang mengatur hubungan diantara mereka sehingga memunculkan suatu sistem yang “anarkis” (Burchil \& Linklater, 1996, p. 98). Analisis dari kaum realis lebih condong kepada negara dalam kaitannya didalam sistem internasional, tetapi konsep anarkis ini tentunya bisa diturunkan kedalam sistem individu didalam masyarakat. Jika dipandang dari konteks individu didalam masyarakat, sebuah sistem masyarakat akan cenderung dinamis dan tidak anarkis jika ada otoritas berwenang yang menaungi suatu masyarakat. Otoritas ini harus mempunyai beberapa syarat antara lain, diakui kedudukannya oleh masyarakat, mempunyai kharisma atau dihormati, 
mempunyai pengaruh yang kuat dalam masyarakat, dan menduduki jabatan tertinggi dalam strata masyarakat. Contoh dari otoritas tertinggi ini bisa berupa lembaga (pemerintah/organisasi) ataupun individu (Raja, Ketua adat, atau Kyai) dimana kesemuanya mempunyai ciri kepemimpinan yang sentralistik.

Berbeda dengan kaum realis, pendukung sosiologi agama aliran Fungsionalis menjelaskan konflik kisruh berawal dari hal-hal yang fundamental. Aliran fungsionalis ini memulainya dengan bertolak dari asumsi dasarbahwa masyarakat adalah suatu sistem perimbangan, dimana setiap kelompok memberikan sumbangannya yang khas melalui peranannya masing-masing yang telah ditentukan demi lestarinya sistem perimbangan sebagai keseluruhan sehingga konflik sosial digunakan sebagai fungsi korektif (Hendropuspito, 1991, p. 26). Dalam pandangan sosiologi fungsionalis, beranggapan bahwa integrasi dalam masyarakat terjadi karena ideide setiap manusia yang beragam sehingga membentuk tugas dan fungsi masing-masing individu dalam sebuah sistem sehingga membentuk perimbangan. Begitu juga sebaliknya, jika ide dari setip individu tidak membentuk perimbangan karena kekuatan dari salah satu ide maka konflik akan terjadi dalam sistem masyarakat tersebut. Secara keseluruhan, paham sosiologi fungsionalis ini menitikberatkan kepada perimbangan ide dari setiap individu dalam sebuah sistem masyarakat.

Sedangkan teori struktural konflik dalam menjelaskan sebuah konflik yang terjadi di dalam masyarakat melakukan pendekatan dalam usahanya untuk memahami dinamika yang terjadi didalam masyarakat. Dijelaskan bahwa di dalam realitas masyarakat, konflik sebagai hal yang harus ada dan kehadirannya tidak dapat ditawar-tawar lagi. Adanya perbedaan kekuasaan dapat dipastikan menjadi sumber konflik dalam sebuah sistem sosial masyarakat dan terutamanya pada masyarakat yang kompleks dan heterogen. Tidak hanya itu, sumber daya yang langka (terutama sumberdaya ekonomi) di dalam masyarakat akan membangkitkan kompetisi diantara pelaku ekonomi yang memperebutkannya dan bukan mustahil akan berujung pada pertikaian akibat tidak meratanya distribusi sumberdaya sehingga dalam banyak kasus kerap menyebabkan konflik terbuka. Selain karena perbedaan kekuasaan konflik juga akan timbul dikarenakan kekuatan-kekuatan yang saling bersaingan dengan mengejar kepentingannya masing-masing akan melahirkan mekanisme ketidakteraturan sosial (social disorder) (Wirawan, 2012, p. 59). Kalau teori-teri yang lain menganalisis konflik dari sudut pandang masyarakat, maka teori struktural konflik ini lebih memandang konflik yang terjadi akibat para pemimpin yang saling berebut kekuasaan serta saling memperjuangkan kepentingannya masing-masing sehingga timbul ketidakseimbangan sistem didalam masyrakat. Selain itu juga kepentingan setiap pemimpin akan memunculkan kelompokkelompok kecil dengan kepentingan yang sama sehingga integrasi dalam masyarakat mungkin akan menjadi sebuah keniscayaan.

\section{Pola Perubahan Sosial Dalam Masyarakat}

Menurut Lauer, perubahan sosial didalam masyarakat merupakan perubahan-perubahan sosial yang terjadi dalam struktur dan fungsi didalam masyarakat itu sendiri. Pandangan serupa dikemukakan oleh Wilbert Moore yang memandang perubahan sosial sebagai perubahan struktur sosial, pola perilaku dan interaksi sosial. Sedangkan menurut Mac Iver perubahan sosial merupakan perubahan yang terjadi dalam hubungan sosial atau sebagai perubahan terhadap keseimbangan (Lauer, 1993, p. 289).

Soekanto berpendapat bahwa setiap manusia selama hidup pasti mengalami perubahan-perubahan dimana perubahan dapat berupa pengaruh yang terbatas maupun luas, perubahan yang lambat dan ada perubahan yang berjalan cepat. Perubahan dapat mengenai nilai dan norma sosial, pola-pola perilaku organisasi, susunan lembaga kemasyarakatan, lapisan-lapisan dalam masyarakat, kekuasaan dan wewenang, interaksi sosial dan sebaginya. Perubahan-perubahan yang terjadi pada masyarakat merupakan gejala normal. Pengaruhnya bisa menjalar dengan cepat ke bagian-bagian dunia lain berkat adanya komunikasi modern (Soekanto, 2009, p. 259). Ada beberapa bentuk perubahan yang terjadi didalam masyarakat, yaitu diantaranya: (Soekanto, 2009, pp. 269272).

a. Perubahan Lambat dan Perubahan Cepat

b. Perubahan Kecil dan Perubahan Besar

c. Perubahan yang dikehendaki (intended-change) dan perubahan yang tidak dikehendaki (unintendedchange)

Pola perubahan sosial yang terjadi didalam masyarakat tradisional yang cenderung stagnan juga sangat dipengaruhi oleh arah dan tujuan dari pemimpin di dalam masyarakat tradisional itu sendiri. Pemimpin yang dimaksud didalam hal ini bukan hanya pemimpin didalam pemerintahan (formal) tetapi pemimpin nonformal seperti ketua adat, tokoh masyarakat, Kyai ataupun pemimpin non-formal yang lain. Pengaruh dari pemimpin didalam masyarakat tradisional sangat berpengaruh terhadap pola yang terjadi, sehingga bisa dikatakan corak dari masyarakat tradisional cenderung sama dengan corak pemimpinnya. Sebagai contoh jika pemimpinnya menganut paham Nahdatul Ulama (NU) maka masyarakat tradisional juga menganut paham yang sama, begitupun seterusnya.

Kyai sebagai tokoh didalam masyarakat tradisional dan merupakan pemimpin non-formal sering melakukan perubahan besar didalam masyarakatnya. Dikatakan perubahan besar karena struktur masyarakat yang diubah memang selalu sejalan dengan apa yang Kyai kehendaki karena azas kepatuhan masyarakat 
kepada Kyai. Horikhosi dalam Auliya (2015) berpendapat bahwa dalam tampilan fisik, Kyai cenderung terus terang, berani, dan cenderung blak-blakan. Namun demikian, hal tersebut juga dipengaruhi oleh keunggulannya dalam memahami dan melakukan kontekstualisasi dalam masyarakat setempat berikut permasalahanpermasalahan yang terjadi dimasyarakat. Selain itu, dalam menyelesaikan permasalahan-permaslahan yang terjadi didalam mayarakat tradisioal, Kyai mampu menjelaskan persoalan teologi yang rumit pada seorang petani yang awam dalam pendidikan yang formal maupun agama (Auliya, 2015, p. 54). Kelebihan yang dimiliki kyai inilah yang selanjutnya menjadikannya sebagai pemimpin dan penentu arah perubahan sosial didalam masyarakat tradisional.

Dalam kajian Geertz, Kyai disebut juga sebagai makelarbudaya(culturalbroker)yang sanggupmenyaring arus informasi yang masuk ke lingkungan santri dan selanjutnya menularkan apa yang dianggap berguna serta membuang apa yang dianggap dapat merusak bagi mereka. Namun peranan penyaringan tersebut akan tidak bisa berjalan dengan baik pada saat arus informasi yang masuk begitu deras sehingga tidak mungkin lagi disaring oleh Kyai. Dalam keadaan demikian, Kyai akan kehilangan peranannya dalam perubahan sosial yang terjadi dan mengakibatkan kesenjangan budaya (cultural lag) dengan masyarakat disekitarnya (Auliya, 2015, pp. 54-55).

\section{Islam Dalam Kultur Masyarakat Tradisional}

Islam sebagai agama mayoritas penduduk di Indonesia memiliki pengaruh besar terhadap pemberian corak serta pola yang muncul didalam masyarakat. Islam sendiri di Indonesia terbagi menjadi islam modern (Muhammadiyah) serta islam tradisional (NU) dimana keduanya mempunyai pola yang berbeda. Islam modern lebihcenderungmenerimapengaruhperkembanganjaman serta tidak terpaku pada pola kepemimpinan sentralistik, sedangkan islam tradisional masih memasukkan tradisi nenek moyang beserta adat budayanya, selain itu islam tradisional juga memiliki ciri kepemimpinan yang sentralistik. Kyai sebagai pemuka (pemimpin) didalam islam tradisional yang cenderung pola kepemimpinannya top-down sudah tentu menerapkan prinsip-prinsip serta ajaran-ajaran islam di dalam pembentukan masyarakat tradisional.

Kalau dilihat dari sudut bahasa, agama dalam bahasa Latin religio yang berarti menghormati apa yang suci dan religare yang berarti untuk mengikat atau kewajiban sehingga agama digambarkan berbagai sistem kepercayaan dan praktek tentang kesakralan dan spiritualitas. Sementara beberapa orang berpikir bahwa agama sebagai sesuatu yang individu karena keyakinan agama dapat sangat pribadi dan juga bisa mewujudkan diri sebagai lembaga sosial. Selain itu, ilmuwan sosial mengakui bahwa agama sangat terorganisir dan terpadu terkait dengan keyakinan, perilaku, dan norma-norma yang berpusat pada kebutuhan sosial dasar dan nilai-nilai (Givern, 2015). Sehingga bisa dikatakan bahwa agama bagi masyarakat adalah merupakan kebutuhan dasar yang tidak dapat dipisahkan dalam kehidupan sehari-hari serta nilai yang terkandung didalam agama akan mampu merubah kepribadian setiap individu hingga sesuai dengan agama yang dianut.

Sejak terbitnya buku Max Weber "Religious Sociology”, perhatian terhadap adanya hubungan antara keyakinan religius dan perilaku ekonomi menjadi semakin menarik, baik dalam sejarah ekonomi mapun dalam sosiologi agama. Karena hubungan tersebut sering dianggap terlalu luas, seringkali perhatian tersebut kemudian dibatasi kepada keyakinan religius tertentu dan perilaku ekonomi. Hal ini menunjukkan bahwa adanya hubungan timbal balik antara struktur sosial dan agama atau sistem keagamaan untuk semua peradaban selama perjalanan sejarahnya (Athoillah, 2011).

Selain kaitan agama dengan ekonomi para tokoh sosiologi menjelaskan tentang kaitan antara agama dengan masyarakat. Kaitan agama dengan masyarakat banyak dibuktikan oleh pengetahuan agama yang meliputi penulisan sejarah dan figur nabi dalam mengubah kehidupan sosial, argumentasi rasional tentang arti dan hakikat kehidupan, tentang Tuhan dan kesadaran akan maut menimbulkan religi, dan sila Ketuhanan Yang Maha Esa. Agama juga merupakan tempat mencari makna hidup yang final dan ultimate serta agama merupakan sumber motivasi tindakan individu dalam hubungan sosialnya dimana pengalaman keagamaannya akan terefleksikan pada tindakan sosial, dan individu dengan masyarakat seharusnya tidak bersifat antagonis. Pengaruh agama dalam kehidupan sosial menyangkut dua hal, yaitu pengaruh dari cita-cita agama dan etika, agama dalam kehidupan individu dari kelas sosial dan group sosial, perseorangan dan kolektivitas, dan mencakup kebiasaan dan cara semua unsur asing agama diwarnainya. (Wirawan, 2012, p. 277). Agama juga akan berfungsi sebagai filter bagi isu-isu dan salah satu komponen budaya (Givern, 2015). Agama ini akan menyaring isu-isu yang berkembang dididalam masyarakat dan agama menerima isu-isu sejalan dengan agama dan membuang yang tidak sejalan dengan agama tersebut. Dengan demikian, masyarakat akan terhindar dari ketidaksejalanan arah tujuan hidup mereka dari norma-norma agama yang sudah diyakini sehingga dengan adanya agama didalam masyarakat maka perubahan sosial yang terjadi akan terus searah sesuai keyakinan agama yang dianut oleh masyarakat tersebut.

Agama dalam hal ini tidaklah selalu diartikan sebagai sesuatu yang dengan keniscayaannya memiliki kebenaran absolut dan berada dalam ruang dan waktu transendennya. Akan tetapi, agama diartikan sebagai bentuk pemahaman manusia terhadap apa yang mereka lihat dalam kitab-kitab suci mereka. Kitab 
suci sendiri merupakan wujud awal pendegradasian keniscayaan kebenaran absolut di atas agar dapat ditangkap, dipahami, dan diamalkan oleh mereka yang mempercayainya dalam batas-batas relativitas yang disebabkan keterbatasan immanensi mereka. Batas-batas relativitas tersebut tampak semakin nyata manakala wujud agama telah berubah menjadi fenomena sosiologis yang tentu saja bersifat lokal dan temporal. Oleh karena itu, ditemukan banyak kesulitan untuk menjelaskan pandangan pandangan Weber di atas ketika ia tidak dibatasi oleh waktu dan tempat tertentu. Hal ini berarti adanya keharusan untuk membatasi fenomena sosiologis yang hendak dijelaskan tersebut sehingga analisis yang diberikan harus ditujukan kepada hal-hal yang lebih khusus, seperti unit-unit sosial yang lebih kecil dan dalam kurun waktu tertentu (Athoillah, 2011).

Islam tradisional merupakan salah satu corak paham keislaman yang paling populer dan banyak dianut oleh masyarakat Indonesia. Paham keislaman ini sering dikonfrontir dengan Islam modernis yang menuduh Islam tradisional sebagai penghambat kemajuan dan membawa kemunduran umat Islam. Berbagai pemikiran yang dilakukan kaum modernis untuk membawa umat Islam kepada kemajuan adalah dengan terlebih dahulu meninggalkan sikap tradisionalnya. Dalam perkembangan selanjutnya, Islam tradisional tidak hanya ditujukan kepada mereka yang berpegang teguh kepada Al-Qur’an dan Al-sunnah, melainkan juga hasil pemikiran (ijtihad) para ulama yang dianggap unggul dan kokoh dalam berbagai bidang keilmuan, seperti “fiqih" (hukum Islam), tafsir, teologi, "Tasawuf”, dan sebagainya. Adapun ciriciri Islam Tradisional antara lain (Admin, 2008):

1. Eksklusif (tertutup) tidak mau menerima pemikiran, pendapat, dan saran yang berasal dari luar, terutama dalam bidang keagamaan karena memandang bahwa hanya kelompoknya saja yang benar, sedangkan kelompok yang lainnya tidak benar.

2. Tidak membedakan antara hal-hal yang bersifat ajaran dengan non ajaran.

3. Berorientasi ke belakang. Menilai berbagai keputusan hukum para ulama di masa lampau lebih agung dan menjadi contoh ideal, yang tidak mungkin dikalahkan oleh para ulama atau sarjana yang muncul kemudian.

4. Cenderung tekstualitas-literalis tanpa melihat latar belakang dan situasi sosial yang menyebabkan ayat Al-Qur`an itu diturunkan, serta pesan yang terkandung di balik satu ayat. Maka mereka meniru segala macam yang dicontohkan Nabi dan ulama masa lampau seperti pola busana nabi yang mengenakan jubah, berjanggut, memakai sorban, makan dengan tangan, tidak menggunakan produk-produk teknologi modern, cenderung kembali ke alam.

5. Tidak membatasi waktu, misalnya belajar di pesantren tanpa batas waktu tertentu.
6. Cenderung tidak mempermasalahkan tradisi masyarakat lokal setempat sebelum agama Islam diterima, yang penting menentramkan hati dan perasaan umat.

7. Cenderung lebih mengutamakan perasaan dari pikiran. Kegiatan ritual keagamaan lebih diperbanyak seperti Zikir, berdoa, mengadakan selamatan bersama, istighosyah bersama, pergi ziarah dan sebagainya.

8. Cenderung bersifat jabariah dan teosentris. Tunduk dan patuh pada Tuhan, pasrah pada takdir.

9. Kurang tertarik pada ilmu pengetahuan dan teknologi modern.

10. Cenderung puas dengan apa yang sudah ada, tidak tertarik pada persaingan global.

Seperti contoh antara Islam dan Jawa sendiri merupakan entitas yang tidak bisa disamakan, tetapi tidak bisa dihilangkan begitu saja. Karena demikian erat hubungannya sehingga membahas Islam di Jawa akan bertemu dengan tradisi Jawa yang sudah melekat kepadanya (Qodir, 2011, p. 153). Islam di tanah Jawa merupakan Islam yang hadir dalam lokalitas Jawa yang berhubungan langsung maupun tidak langsung dengan kebiasaan-kebiasaan Hindu. Berbeda dengan Islam yang berada di luar Jawa, apalagi di Timur Tengah dimana agama ini awal mula disebarkan. Dalam khazanah antropologi, Islam di Jawa sering dikenal dengan Islam dalam tradisi rakyat-massa, atau popular tradition dan bukan lagi high tradition. Oleh karena itu, Islam di Jawa dianut penuh oleh keanekaragaman dan bukan hanya mistik, tetapi sekaligus dalam bahasa skriptualisme adalah penuh akidah (Qodir, 2011, p. 156).

Menurut Durkheim, agama adalah suatu sistem terpadu dari kepercayaan dan praktek terhadap hal-hal yang suci. Selain itu, Durkheim juga tidak peduli dengan berbagai pengalaman religius individu melainkan dengan aktivitas komunal dan obligasi komunal yang partisipasi dalam kegiatan keagamaan yang ditimbulkan (Coser, 2015, pp. 136-139). Sedangkan bagi muslim tradisional, bahasa al-Qur'an merupakan landasan bagi pengetahuan mutlak tentang dunia, tetapi berbeda dengan muslim liberal yang menganggap bahasa alQur'an sederajat dengan hakikat wahyu namun isi dan makna perwahyuan pada dasarnya tidak bersifat harfiahverbal karena kata-kata dalam al-Qur'an menurut kaum ini tidak secara tidak terbatasi oleh kata-kata tetapi lebih kepada makna sesungguhnya yang hendak diungkapkan/ diwahyukan melalui bahasa. Berkurangnya tekanan budaya Barat menjadikan Islam Liberal justru tunduk kepada tekanan Muslim Tradisional dan fundamentalis. Karena tidak lagi mempertahankan aspek liberalisme Barat, kaum Muslim Liberal menjadi mudah untuk rujuk kembali dengan golongan tradisional dan fundamentalis (Binder, 2001, pp. 5-7). Kerentanan yang terjadi pada muslim liberal dipengaruhi juga dari sistem kepemimpinan yang tidak sentralistik sehingga 
rawan terjadi gesekan antar pengikut satu dengan yang lain ataupun kelompok satu dengan yang lain meskipun sesama muslim liberal.

Doktrin Politik Liberal berpangkal dari keyakinan bahwa kesepakatan demi kebaikan bersama bagi kelompok bersejarah manapun bisa dicapai menggunakan wacana rasional. Doktrin liberal adalah suatu gambaran era modernisasi dari suatu masyarakat dimana ciri utamanya adalah mengandalkan rasionalitas daripada rasa atau perasaan. Doktrin liberal mengasumsikan adanya komunitas politik heterogen, keanggotaan yang tetap, dan peduli terhadap kepentingan bersama. Selain itu, komunitas politik ini bersifat lintas seajarah dimana tidak ada senioritas atau junioritas dalam kelompok masyarakat ini. Menurut Leonard Binder, Politik liberal tidak cocok bagi komunitas religious mutlak, kecuali mereka sendiri yakin bahwa Tuhan telah menganugerahi mereka dengan nalar dan kehendak masing-masing dan bahwa mereka sendiri tidak tahu pasti apa yang dikehendaki oleh Sang Khalik (Binder, 2001, pp. 4-5).

\section{Peran Kyai Dalam Masyarakat}

Didalam struktur masyarakat tradisional memiliki pemimpin non-formal seperti tetua adat, sesepuh masyarakat dan juga Kyai yang menjadi acuan bagi masyarakat tradisional disamping pemimpin formal seperti kepala desa atau Bupati. Kyai sebagai salah satu pemimpin non-formal di dalam masyarakat tradisional dianggap sebagai pemimpin spiritual atau pemimpin dalam bidang keagamaan. Hampir setiap kegiatan dilakukan atau permasalahan yang dialami oleh masyarakat meminta pertimbangan kepada Kyai, hal inilah mengapa sosok Kyai di dalam masyarakat tradisional sangat dipatuhi dan di perhitungkan keberadaannya.

Menurut Nurkholis Majid, kata “Kyai” bermakna tua atau dalam bahasa jawa yaitu "Yahi", tetapi di situ juga terkandung makna rasa pensucian pada orang tua sebagaimana kecenderungan yang umum di kalangan orang Jawa sehingga "Kyai" tidak saja berarti tua (yang kebetulan saja maknanya sama dengan syaikh dalam bahasa Arab) tetapi juga berarti sakral, keramat, dan sakti. Maka benda-benda yang dianggap keramat, seperti keris pusaka, tombak pusaka, gamelan pusaka, dan pusaka-pusaka keraton juga disebut "Kyai" (Majid, 1997, p. 20). Kesakralan dan kesaktian seorang Kyai yang masih diyakini masyarakat tradisional hingga sekarang ini telah ikut membentuk nama dari Kyai menjadi besar dan disegani sebagai sesosok yang sakral.

Selain itu, pengertian Kyai secara umum banyak diberikan kepada para pendiri Pesantren, yang sebagai muslim terpelajar telah membaktikan untuk Allah dan menyebarluaskan serta memperdalam ajaran-ajaran dan pandangan Islam melalui kegiatan-kegiatan Pesantren (Arifin, 1993, p. 14). Gus Dur dalam pengantar tulisannya yang berjudul Kyai dan Perubahan Sosial menyatakan bahwa harus ada kelompok dinamis yang akan memulai memodernisasi, walaupun masih ada keberatan dari mereka yang mempertahankan tradisi. Selain itu, Gus Dur juga melanjutkan bahwa modernisasi dihadapkan kepada tradisi, perubahan kepada status $q u o$, dinamika pada keadaan statis. Upaya modernisasi dengan sendirinya adalah pengikisan sikap tradisional, ini adalah semboyan semua pemrakarsa modernisasi tanpa terkecuali termasuk negeri Indonesia di akhir dasawarsa enam puluhan dan dasawarsa tujuh puluhan (Horikoshi, 1987). Pesan singkat dari Gus Dur ini mengisyaratkan kepada seluruh Kyai di Indonesia untuk bisa memberikan nafas perubahan bagi masyarakat tradisional dan bukan hanya menerima keadaan masyarakat yang cenderung statis. Dengan melakukan perubahan maka tentunya harapan besar dari Gus Dur adalah masyarakat tradisional tidak lagi statis tapi lebih dinamis dengan mengikuti perkembangan jaman.

Kalau menilik sejarah, kita tahu bahwa para agamawan seperti Kyai sejak dahulu dinilai sebagai penghambat bagi kemajuan karena tidak ada kemajuan tanpa perubahan, maka mudah saja tudingan diteruskan kepada mereka sebagai pihak yang menentang perubahan. Mereka yang mengatakan agamawan tidak dapat membawa perubahan sosial beranggapan para agamawan merupakan sebuah "tradisi" yang stagnan, tidak dinamis. Objek analisis dalam studi tentang gerakan kemasyarakatan adalah pertama, individu, pusat perhatiannya yaitu kepada pada persoalan mengapa dan bagaimana individu-individu menggabungkan diri dalam sebuah gerakan-gerakan kemasyarakatan dan pada ciri-ciri khas yang membedakan individu-individu yang terlibat dalam sebuah gerakan. Kekuatan-kekuatan kultural menjadi riil dan dapat diteliti secara empiris tatkala mereka berubah bentuk kedalam motivasi, predisposisi, dan kecenderungan pribadi (Mirsel, 2004, p. 56). Para aktifis pergerakan sosial yang beranggapan bahwa agamawan sebagai penghambat kemajuan pada akan sangat sulit merubah masyarakat tradisional karena pengaruh yang kuat dari Kyai serta budaya yang melekat didalam masyarakat tradisional yang cenderung menurut apa perintah pemimpin mereka.

Bila dilihat dari segi sosial, kekuatan Kyai terletak pada dua hal yaitu memiliki perasaan kemasyarakatan yang dalam dan tinggi serta selalu melandaskan sesuatu kepada kesepakatan bersama. Kedua hal inilah yang membentuk posisi Kyai dalam masyarakat menjadi sangat kuat, sehingga sosok seorang Kyai berpengaruh sangat kuat sebagai figur pemimpin informal. Kalau ditelusuri lebih jauh, salah satu faktor yang membentuk kebesaran Kyai adalah faktor teologis, karena dikalangan masyarakat muslim Kyai dianggap adalah keturunan Nabi. Selain itu, faktor karisma yang terbentuk secara ilmiah juga ikut menentukan tinggi rendahnya pengaruh

Kyai di dalam masyarakat terutama masyarakat tradisional(Muhibbin, 2012, pp. xi-xii). Selain itu, ada dua 
faktor utama yang mendukung kenapa Kyai mempunyai tempat terhormat dalam pandangan masyarakat secara umum. Pertama, Kyai adalah orang yang berpengetahuan luas khususnya ilmu agama, sehingga penduduk (desa) belajar pengetahuan kepadanya. Kedua, Kyai biasanya berasal dari keluarga berada, meskipun jarang ditemukan Kyai yang miskin pada saat baru memulai pengajaran Islam (Turmudi, 2003, pp. 95-96). Dengan tingginya pengaruh Kyai dalam masyarakat maka secara tidak langsung memposisikan Kyai sebagai otoritas tertinggi didalam masyarakat dan bahkan pemerintahan formal seperti pemerintahan desa bisa tunduk kepada Kyai.

Selain itu, Kyai dalam masyarakat juga berperan sebagai tokoh agama yang meliputi peran spiritual, pendidikan, agent of change, dan sosial budaya serta berperan sebagai figure yang terlibat dalam politik baik sebagai partisipan, pendukung maupun aktor (Turmudi, 2003, p. 96). Peran spiritual Kyai bisa kita lihat dimana Kyai dipandang oleh masyarakat tradisional sebagai tokoh yang paling paham tentang agama serta apapun nasehat atau petuah dari Kyai dianggap sudah sesuai dengan syariat islam. Peran pendidikan Kyai bisa kita lihat dimana Kyai memberikan pengajaran agama baik bagi penduduk sekitar tempat tinggalnya atau didalam lembaga pendidikan yang dia bangun.

\section{SIMPULAN}

Penempatan sosok Kyai sebagai tokoh agama di dalam masyarakat tradisional telah secara perlahan membentuk suatu kepemimpinan baru selain kepemimpinan pemerintahan. Bentuk dari kepemimpinan baru ini bisa disebut sebagai kepemimpinan non-formal dimana dalam masyarakat tradisional kepemimpinan non-formal mempunyai pengaruh lebih kuat dibandingkan pemimpin formal seperti Kepala Desa ataupun Bupati. Pengangkatan Kyai sebagai pemimpin non-formal dikarenakan struktur masyarakat tradisional masih sangat kental dengan budaya agama dan Kyai dianggap sebagai spiritual atau pemimpin dalam bidang keagamaan. Dengan kuatnya posisi Kyai dalam masyarakat tradisional sehingga terbentuklah tokoh sentral didalam mayarakat tradisional tersebut.

Terbentuknya tokoh sentral non-formal yang ditaati oleh masyarakat tradisional maka akan bisa menjadi sistem kontrol terhadap masyarakat tradisional tersebut. Sistem kontrol ini akan memberikan arah kepada masyarakat tradisional kemana mereka harus berjalan dan bagaimana mereka harus berbuat. Karena Kyai adalah tokoh sentral dalam bidang keagamaan maka arah pergerakan dari masyarakat tradisional yang dipimpinnya akan bercorak keagamaan juga.

Selain itu karena Kyai memiliki peran dalam masyarakat tradisional yaitu sebagai agent of change (agen perubahan), maka cepat ataupun lambatnya perkembangan masyarakat tradisional sangat dipengaruhi juga oleh Kyai. Dengan melihat kesakralan sosok dari Kyai tersebut, maka apapun yang dikehendaki atau diperintahkan oleh Kyai seolah-olah menjadi sebuah sabda yang harus diikuti oleh masyarakat tradisional karena mereka menganggap pasti sudah sesuai dengan syariat islam. Kepatuhan masyarakat tradisional kepada sosok Kyai pada akhirnya akan membentuk sistem sentralistik dimana Kyai sebagai pemimpinnya, sehingga perubahan yang terjadi pada masyarakat tradisional bisa dipastikan akan sejalan atau searah dengan jalan pikirin dari Kyai itu sendiri yaitu jika Kyai menghendaki masyarakatnya statis, maka pola di masyarakat tradisional juga cenderung statis dan begitupun sebaliknya. Dengan demikian, Kyai mempunyai fungsi yang sangat vital didalam membentuk pola atau corak dari masyarakat tradisional dimana Kyai memiliki dua fungsi utama yaitu sebagai pemimpin non-formal serta agen perubahan.

Dengan terbentuknya sistem sentralistik dalam masyarakat tradisional dimana Kyai sebagai menduduki fungsi kontrol utama maka seperti dikatakan kaum realis bahwa jika ada otoritas tertinggi yang menaungi suatu kelompok atau masyarakat maka terwujudlah perdamaian. Maka dari itu jika suatu negara atau masyarakat suatu negara yang selalu terjadi konflik tak kunjung selesai, solusi utamanya adalah membentuk sistem sentralistik dimana menempatkan tokoh atau lembaga yang memiliki kharisma tinggi dan dipatuhi oleh seluruh rakyatnya. Dengan terbentuknya sistem sentralistik tersebut maka perdamaian dalam negara akan segera terwujud. Selain itu juga perubahan menuju arah kemakmuran akan bisa cepat diwujudkan.

\section{DAFTAR PUSTAKA}

Admin. (2008, September 16). Islam Tradisional. Retrieved Februari 26, 2016, from http:/www.sabda.org/: http://www.sabda.org/publikasi/ 40hari/2008/16

Arifin, I. (1993). Kepemimpinan Kyai : Kasus Pondok Pesantren Tebuireng. Malang: Kalimasaheda Press.

Athoillah, M. A. (2011, Januari 01). Agama dan Perubahan Sosial. Retrieved Februari 15, 2016, from http://www.knowledge-leader.net/: http:// www.knowledge-leader.net/2011/01/agamadan-perubahan-sosial/

Auliya, S. (2015). Kiai dan Pembangunan Institusi Sosial. Yogyakarta: Pustaka Pelajar.

Binder, L. (2001). Islam Liberal ( Kritik Terhadap Ideologi-Ideologi Pembangunan). Yogyakarta: Pustaka Pelajar.

Burchil, S., \& Linklater, A. (1996). Teori-Teori Hubungan Internasional. Bandung: Nusa Media.

Coser, L. A. (2015, November 14). Introduction to Sociology. Retrieved Februari 15, 2016, from 
http://www.cf.ac.uk/: http://www.cf.ac.uk/ socsi/undergraduate/introsoc/durkheim6.html

Givern, R. M. (2015, Desember 25). Introduction to Sociology. Retrieved Februari 15, 2016, from https://opentextbc.ca:https://opentextbc.ca/ introductionosociology/chapter/chapter15religion/

Hendropuspito. (1991). Sosiologi Agama. Yogyakarta: Kanisius.

Horikoshi, H. (1987). Kyai dan Perubahan Sosial. Jakarta: P3M.

Lauer, R. H. (1993). Perspektif tentang Perubahan Budaya Sosial. Jakarta: Rineka Cipta.

Majid, N. (1997). Bilik-Bilik Pesantren: Sebuah Potret Perjalanan. Jakarta: Paramadina.
Mirsel, R. (2004). Teori Pergerakan Sosial. Yogyakarta: Resist Book.

Muhibbin. (2012). Politik Kyai VS Politik Rakyat. Yogyakarta: Pustaka Pelajar.

Qodir, Z. (2011). Sosiologi Agama ; Esai-Esai Agama di Ruang Publik. Yogyakarta: Pustaka Pelajar.

Sandarupa, S. (2014). Kebudayaan Toraja Modal Bangsa, Milik Dunia. Sosiohumaniora, 1 -9.

Soekanto, S. (2009). Peranan Sosiologi Suatu Pengantar. Jakarta: Rajawali Press.

Turmudi, E. (2003). Perselingkuhan Kiai dan Kekuasaan. Yogyakarta: LKiS.

Wirawan, I. (2012). Teori-Teori Sosial dalam Tiga Paradigma. Jakarta: Kencana Prenada Media Group. 